\title{
Chapter 4 \\ Antagonisms of Adaptation: Climate Change Adaptation Measures in New Orleans and New York City
}

\author{
Kevin Fox Gotham and Megan Faust
}

\subsection{Introduction}

Scientists increasingly point to the possibility of multiple abrupt negative consequences associated with anthropogenic climate change. Climate change poses risks to many environmental and economic systems - including agriculture, public infrastructure, ecosystems, and human health — and presents a significant financial risk to federal, state, and local governments (US Global Change Research Program 2011; National Research Council 2012a, b). Scientists expect climate change to threaten coastal cities and ecosystems with rising sea levels, elevated tidal inundation, increased storm and flood frequency and intensity, and accelerated erosion and saltwater intrusion (Blum and Roberts 2009; Intergovernmental Panel on Climate Change [IPCC] 2014; Karl et al. 2009). As observed by the US Global Change Research Program (USGCRP), the impacts and costliness of weather disasters resulting from floods, drought, and other events such as tropical cyclones will increase in significance as what are considered "rare" events become more common and intense due to climate change (Karl et al. 2009). Overall, according to the National Research Council and the US Global Change Research Program, changes in Earth's climate-including higher temperatures, changes in precipitation, rising sea levels, and more intense and frequent severe weather events-are underway and expected to grow over time. These risks not only imperil the longterm sustainability of cities and communities, but they could create significant fiscal problems for local, state, and federal governments.

This chapter identifies climate change adaptation measures implemented in postSandy New York City and post-Katrina New Orleans and examines their conflictual and contradictory dynamics and impacts. Climate change adaptation measures are an amalgam of government policies, socio-legal regulations, statutes, and laws to

K. F. Gotham $(\varangle) \cdot$ M. Faust

Sociology and Urban Studies, Tulane University, New Orleans, LA, USA

e-mail: kgotham@tulane.edu; mfaust1@tulane.edu 
reduce current and future vulnerability to the negative impacts of climate change (e.g., global warming and sea-level rise) and strengthen social resilience (IPCC 2014). As a risk management strategy, climate change adaptation represents adjustments to natural or human systems in response to actual or expected climate change. The broad goal is to help protect vulnerable sectors and communities that might be affected by changes in the climate (GAO 2013). For example, adaptation measures include raising river or coastal dikes to protect infrastructure from sealevel rise, building higher bridges, and increasing the capacity of storm water systems. State and local authorities are responsible for the planning and implementation of many types of infrastructure projects, and decisions at these levels of government can affect insurance rates for businesses and homeowners as well as influence patterns of economic development. While implementing adaptive measures may be costly, policy-makers and elected leaders are increasingly recognizing that the cost of inaction could be greater as damage from weatherrelated events becomes more expensive (GAO 2009, 2016).

This paper addresses the ways in which the decentralized and fragmented structure of policy-making and implementation in the United States both constrains the process of formulating and implementing comprehensive climate change adaptation measures and encourages cities to respond to climate change using their own distinctive policy measures. Much social science research has focused on the uneven manner in which climate change adaptation agendas are unfolding in a diverse set of urban contexts (Dunlap and Brulle 2015; Bulkeley and Castán Broto 2013; Bulkeley and Betsill 2013; Burch et al. 2014; Dale et al. 2018; Morrison et al. 2017; McCann 2017). In this paper, we adopt an "encompassing" comparative approach to explain how local climate change developments in New York City and New Orleans reflect, share characteristics with, and contribute to broader socioeconomic and political trends in the United States. Encompassing comparison seeks to understand how local actions and events express the interaction of local-global forces and relations including institutional forms, regulatory strategies, and governance projects. We conceptualize the pairing of climate change adaptation measures as an encompassing comparison, which, according to Charles Tilly (1984, p. 83), "places different instances at various locations within the same system, on the way to explaining their characteristics as a function of their varying relationships to the system as a whole." While our comparison of two cities may lack sufficient scope for statistical generalization, we believe our encompassing mode of comparative analysis provides for breadth of generalization and depth of description that is not possible in quantitative analyses. Our comparison provides an opportunity to reflect upon how decisions surrounding climate change adaptation measures take place in a larger political economy of policy-making that shapes and constraints local actions. 


\subsection{Risk, Resilience, Mitigation, and Adaptation}

Over the last decade or so, scholars and policy-makers have debated the steps governments can take to reduce risk of extreme events through climate change adaptation and align such adaptation with broader resilience efforts (Gotham et al. 2011; Gotham and Campanella 2010, 2011). Risk refers to situations or conditions that pose a threat to human health, quality of life, and community well-being (for an overview, see Tierney 2014). Risk is a relational term that is closely connected to the notion of resilience, which the National Research Council (2012b, p. 5) defines as the "ability to prepare and plan for, absorb, recover from, and more successfully adapt to adverse events." In the scholarship on climate change, resilience implies regulatory and policy actions to reduce vulnerabilities to the effects of severe weather and to adapt to the effects of climate change. Scholars theorize that two related sets of actions - climate change mitigation and climate change adaptationmay be able to enhance resilience by reducing risk. Mitigation refers to human actions to reduce the sources of greenhouse gases (GHGs) that contribute to global warming and, in turn, sea-level rise.

We follow climate change scientists in viewing climate change mitigation and adaptation as conceptually separate and analytically distinct. We recognize that federal agencies such as FEMA and the Army Corps of Engineers have used the term hazard "mitigation" for decades to refer to activities designed to reduce hazard risks. Flood risk reduction, for example, involves a combination of structuralfocusing on reducing the probability of flooding - and physical and nonphysical nonstructural measures that focus on reducing the consequences of flooding (US Army Corps of Engineers 2018). At the individual property level, nonstructural mitigation options include elevating a building to or above the area's base flood elevation, relocating the building to an area with less flood risk, or purchasing and demolishing the building and turning the property into green space. In addition, nonstructural risk reduction measures would include flood insurance, floodplain mapping, improving response capacity, improving post-disaster assessment and communication capacity, and developing more effective strategies to communicate risk and mitigation activities to various stakeholders. Nonstructural mitigation is akin to adaptation. FEMA supports a variety of nonstructural flood mitigation activities to reduce flood risk.

Because mitigation is intended to reduce the harmful effects of climate change, it is part of a broader policy framework that also includes adaptation to climate impacts. Climate change adaptation refers to actions taken by governments, nonprofit organizations, and private firms to reduce the loss of life and property by lessening the impacts of adverse climate change events such as weather-related disasters. Climate change adaptations can also be classed as either process-oriented measures-aimed at developing information systems, social structures, and governance needed to support adaptation-or outcome-oriented actions, measures taken to reduce vulnerability and exploit opportunities that arise from a changing climate. Climate change adaptation measures can be effect-oriented in the sense of 
building flood protection or cause-oriented by adopting approaches such as changing the location of areas for new housing development. Climate change adaptation includes activities such as restoring wetlands and coastal areas to control erosion, improving the quality of road surfaces to withstand hotter temperatures, protecting critical facilities against the negative effects (e.g., inundation) of sealevel rise, and creating permeable surfaces and "green roofs," or roofs partially or completely covered with vegetation, in cities to absorb excess rainfall, provide insulation, and help lower urban air temperatures (Wise et al. 2014; for an overview, see IPCC 2014). Climate change adaptation measures can be proactive and/or reactive. Governments may plan and adopt adaptation measures in advance, establish them in the aftermath of a major disaster, or create them in response to local pressures. In addition to large-scale infrastructure measures to adapt to climate change, governments may also implement policies and regulations to incentivize people to change their behaviors. This approach includes motivating them to use less water, encouraging farmers to plant different crops, and urging more households and businesses to purchase flood insurance.

Many researchers and policy-makers consider climate change a global problem that demands international action and global solutions. But sociologists and others have documented that the effects of global climate change will not be equally distributed around the world, for "many of the countries least responsible for the rise in greenhouse gases will be most likely to feel its impacts in changes in weather, sea-levels, human health costs, and economic hardships" (Nagel et al. 2010, p. 17). The unequal burdens inflicted by climate-related disasters and limited disaster response capacities will exacerbate these inequalities and likely generate unforeseen consequences. Variations in individual, community, and national vulnerability to the impacts of climate change are only part of this global structure of inequality. As the 2007 Intergovernmental Panel on Climate Change (IPCC) report notes, there is an unequal distribution of impacts and vulnerabilities to climate change associated with social class and age in both developed and developing countries: "vulnerability to climate change can be exacerbated by other stresses. These arise from, for example, current climate hazards, poverty and unequal access to resources, food insecurity, trends in economic globalization, conflict and incidence of diseases such as HIV/AIDS" (2007, p. 14). Thus, the impacts of climate change are not spread evenly, and its effects will be felt by different social groups in radically different ways.

The ways in which climate change is closely intertwined with state policymaking, institutional arrangements, and political economy is one of the reasons why it has proven so unique an issue to address internationally as a global problem. Conceptualizing climate change as a global-local issue and using comparative analyses draws attention to different socio-spatial inequalities, local and regional histories and geographies, and their implications for communities. These concerns bring explicit temporal and spatial dimensions to our understanding of the local impacts of global climate change. Climate change adaptation measures are activated and reproduced through the concrete actions taken by state actors, elected leaders, economic elites, and other powerful organized interests. A core assumption of this 
agent-centric approach is that the adoption of climate change adaptation actions does not develop out of an inevitable and unalterable structural necessity but rather in a contingent manner; it results from the conscious actions taken by individual decision-makers in various institutions, organizations, and communities acting under particular historical circumstances. This emphasis on contingency and agency compels us to examine the actions of human agents, organizations, and interest groups in an effort to grasp how larger climate change dynamics and effects occur at the local level. Underscoring the importance of space and time in climate change research means that any explanation of why and how climate change policy actions develop will need to take account of where and when they develop.

In the sections below, we address the obstacles to climate change adaptation by focusing on the dynamic ways in which antagonisms-incongruences and inconsistencies between goals, implementation strategies, and outcomes-develop and persist. Scholars have used terms such as "barriers," "obstacles," "tensions," and "contradictions" to describe the difficulties that hinder the formulation and implementation of climate change adaptation actions (Eakin et al. 2014). Lack of resources to meet the costs of adaptation can be a financial barrier. Lack of administrative and/or political capacity can be an institutional barrier to adaptation. Collective opposition and political mobilization against adaptation can be a socialcultural barrier. Finally, gaps in climate change knowledge and the transmission of information can create an information barrier. Eisenack et al. (2014, p. 867) suggest that the "growing literature on barriers to adaptation reveals not only commonly reported barriers, but also conflicting evidence, and few explanations of why barriers exist and change."

In attempt to move beyond debates over discrete barriers to climate change adaptation, Pelling et al. (2015) have developed the concept of transformation "as an adaptive response to climate change" that can open a range of novel policy options. In their work, transformative adaptation is a multifaceted concept that researchers can use to describe responses that produce nonlinear changes in systems or their host social and ecological environments. The concept also raises distinct ethical and procedural questions for decision-makers and "foregrounds questions of power and preference that have so far been underdeveloped in adaptation theory and practice" (p. 113). The concept of transformative adaptation dovetails with the notion of transformative resilience developed by Gotham and Campanella (2011) and suggests that we view climate change adaptation in a multidimensional fashion, for example, as a political decision point, an opportunity for socio-spatial change, and a prospect for resistance to dominant developmental pathways.

Through a comparison of New Orleans and New York, our research helps to explain the major antagonisms of adaptation and provides insights on how to overcome them to enhance societal resilience to climate change risks. Following the logic of encompassing comparison, we analytically juxtapose policy trajectories and institutional arrangements rather than compare discrete units or fixed variables. The chapter offers a sociological critique of the dominant approaches to adaptation and highlights the institutional and social antagonisms that are shaping the implementation of climate change policy in each city. 
Our theorization of the facilitative and discouraging power of state action in the development of climate change adaptation measures focuses on the state as an actor and as an institutional structure. The state comprises many actors that can formulate and implement different policies and socio-legal regulations to respond to climate change. State governments have special charters and can make property rights decisions to alter the organization of firms and corporate hierarchies. Through legislative debate and compromise, the US Congress makes laws, holds hearings to inform the legislative process, conducts investigations to oversee the executive branch, and represents voting constituencies and states in the federal government. Courts can determine the meaning and effect of laws passed by the state legislatures. Over the decades, US judges have played aggressive roles in interpreting policymaking and economic governance (Campbell and Lindberg 1990).

As an institutional structure, the state power and authority are fragmented and restricted to the extent that state and local governments exercise political authority within their own geographical areas. The existence of 50 separate governments combined with hundreds of municipalities in metropolitan areas has played an important role in the development of different markets, real estate financing, and land-use policies and regulatory strategies. For the most part, laws and regulations pertaining to economic activity and investment are locally based. These laws and regulations include, among many others, recording regulations, banking laws, zoning laws, subdivision regulations, private deed restrictions, land-use regulations, building codes, insurance laws, and property tax law (Feagin and Parker 2002; Gotham 2006, 2009). At the same time, local laws and socio-legal regulations establish institutional practices and rules of exchange that coordinate local economic activity among organizations in a particular economic sector (residential, commercial, or industrial activity) and, more importantly, create distinctive locations for policy-making, investment, and economic activity. The implication is that the decentralized and fragmented institutional structure of the state has influenced the development of legal forms that reinforce the place specificity of climate change adaptation measures thereby fostering local uniqueness and innovation (Gotham 2006).

\subsection{Global Climate Change Risk in New York City and New Orleans}

The New York City metropolitan area, with 23 million residents and approximately 3700 miles of tidal coastline, faces a severe social-ecological threat from climate change-driven warming and sea-level rise. The New York City Panel on Climate Change (NPCC), an organization that examines climate change vulnerability and prepares projections for the City and metropolitan region, contends that extreme weather will increase in frequency and severity and that the climate will become more variable. Climate projections encompass a wide range of possible outcomes: 
mean annual temperature is projected to increase between 4.1 and $6.6^{\circ} \mathrm{F}$ by the 2050s and between 5.3 and $10.3{ }^{\circ} \mathrm{F}$ by the 2080s; frequency of heat waves is projected to triple by the 2050s to 5 to 7 heat waves per year; sea level is expected to continue rising by 11 to 21 inches by the 2050 s and by 18 to 39 inches by the 2080s, a rate that exceeds the global average in relative sea-level rise. New York City has experienced the devastating effects of coastal storms, most recently during Hurricane Sandy, as well as flooding in low-lying areas during high tides. Sea-level rise is projected to increase the depth, extent, and frequency of flooding from storm surge and during high tides (Horton et al. 2015; New York City Mayor's Office 2015).

Like New York, the New Orleans metropolitan area constitutes a highly cited example of a region experiencing the leading edge of climate-related stresses that are widely anticipated to affect coastal regions worldwide (Hallegatte et al. 2013). Given its low elevation and susceptibility to storm surge, extreme storm events and sea-level rise stand out as two of the most severe consequences of climate change in New Orleans and much of southern Louisiana. González and Törnqvist (2006, 2009) show that the preindustrial millennium (600 to 1600 AD) witnessed a rate of sea-level rise of $-0.55 \mathrm{~mm} \mathrm{yr}^{-1}$ in coastal Louisiana. In contrast, the past century has seen rates of at least $2 \mathrm{~mm} \mathrm{yr}^{-1}$, roughly in line with the global average and a fourfold increase in the rate of relative sea-level rise (IPCC 2013). Moreover, modeling assessments consistently point toward an increase in hurricane intensity with global warming. Hurricanes strike the Louisiana coast with a mean frequency of 2 every 3 years (Kolb and Saucier 1982). In 2005, Hurricane Katrina forced the largest and most abrupt displacement in US history with approximately 1.5 million people evacuated from the Gulf Coast region. Using storm surge models, scientists predict a doubling of Hurricane Katrina-magnitude events over the next century (Grinsted et al. 2013; Holland 2012).

For New Orleans, climate-related environmental change coalesces with other non-climate stressors such as wetland loss and land subsidence. Louisiana harbors approximately 40 percent of the contiguous United States' coastal wetlands yet accounts for almost 80 percent of wetland loss. Louisiana has been losing coastal wetlands since at least the 1930s, but the long-term rate of land loss has slowed since its peak in the 1970s, according to the Department of the Interior's US Geological Survey (Couvillion 2017). In addition to subsidence and accelerated sea-level rise, the dredging of about $15,000 \mathrm{~km}$ of canals in the Mississippi River Delta area, primarily for oil and gas infrastructure, has led to widespread saltwater intrusion and ecosystem degradation. However, the fundamental cause of wetland loss is the isolation of the delta plain from sediment input due to the embankment of the Mississippi and Atchafalaya Rivers by artificial levees. Since embankment was completed in the 1930s, the majority of the Mississippi River sediment load has been lost to the deeper waters of the Gulf of Mexico, where the mouth of the river debouches at the shelf edge rather than near shore and inland areas that would replenish the delta plain (Campanella 2017).

Our comparative analysis of climate change adaptation measures in New York and New Orleans suggets two sets of intersecting factors that pose interesting 
conditions for studying climate change responses. On the one hand, both urban regions represent global climate change's "canaries in the coal mine" in the United States. These highly sensitive regions face a future of rising relative sea level, increased frequency and destructiveness of storm events, extreme vulnerability to flood trauma, and potential for major displacement. Scientists view the two regions as harbingers of climate change impacts to come for coastal ecosystems worldwide (Kent 2012; Reed et al. 2015; Wang et al. 2011). On the other hand, both cities constitute the leading edge of socio-legal experimentation, regulatory inventiveness, and policy innovation that will likely offer new approaches and strategies to help other cities adapt to climate change. Currently, planners and policy-makers debate various policies to reduce coastal risk, and major coastal restoration projects, climate change adaptation, and mitigation efforts are currently underway (Gotham 2016a, b; Gotham and Cheek 2017; Gotham and Cannon 2018; Gotham and Powers 2017; Peyronnin et al. 2013; Fischbach et al. 2012). Yet the level at which elected leaders and policy-makers understand the causes and consequences of climate change, as well as the extent to which they regard climate change as harmful to the ecological and economic sustainability of the two cities and regions, is not known. These concerns underpin the need to examine the local and regional dynamics of climate adaptation policy-making and implementation in detail.

\subsection{Long-Term Sustainability Challenges Facing New York City and New Orleans}

Both New York City and New Orleans face long-term sustainability challenges related to the distinctive and peculiar system of local, state, and federal relationships and financing arrangements in the United States (Gotham and Greenberg 2014). As a distinctive configuration of organizations, the agencies of the different branches of the federal government, as well as agencies at the state and local government levels, are predisposed to struggle and conflict over funding amounts and mechanisms of financing. Insofar as the different parts of local, state, and federal governments have overlapping responsibilities for policy-making, contradictory policy actions and political stalemate are possible. Indeed, the institutionally fragmented nature of US federalism has systematically produced a variety of conflicts and contradictions in many areas of policy-making including economic policy, defense policy, transportation policy, housing policy, regulatory policy, hazard mitigation and disaster response policy, and so on (Campbell and Pedersen 2014; Gotham 2012; Gotham and Wright 2009; Hogan and Howlett 2015). As long as different parts of local, state, and federal governments provide different arenas of access to political actors and organized interests, then political conflict and struggle are possible. Moreover, we can expect conflicting policy actions and policy outcomes to the extent that these actors pursue their interests in different arenas. 
Over the last decade, the US federal government has developed a number of climate change adaptation plans that have intersected with local efforts to address urban resilience. In June 2013, President Obama issued the Climate Action Plan, which describes the federal government's existing and planned efforts to prepare for the impacts of climate change and set strategic priorities for the country. For example, the plan directs federal agencies to take appropriate actions to reduce risk to federal investments, specifically calling on them to update their flood risk reduction standards. The plan also established a federal flood risk management standard in January 2015, and implementation guidelines were issued in October 2015 (Executive Order No. 13690). In November 2013, President Obama also issued Executive Order 13653, which directed federal agencies to develop or update comprehensive adaptation plans by describing how they would consider improving climate change adaptation and resilience measures. By 2014, almost 40 federal agencies had created climate change adaptation plans. In addition, several crosscutting interagency plans had been developed to address challenges and improve resilience to climate impacts (Interagency Climate Change Adaptation Task Force 2011).

One example of the antagonistic nature of the formulation and implementation of climate change adaptation measures is the efforts the Trump Administration took to rescind the two Obama Administration executive orders mentioned above. On March 28, 2017, President Trump revoked Executive Order 13653 that aimed to promote (1) engaged and strong partnerships and information sharing at all levels of government; (2) risk-informed decision-making and the tools to facilitate it; (3) adaptive learning, in which experiences serve as opportunities to inform and adjust future actions; and (4) preparedness planning. On August 15, 2017, President Trump revoked Executive Order 13690 in an effort to streamline federal environmental review and approval of major infrastructure projects located in flood-prone areas. The Obama Administration's Executive Order 13690 (2015) required federally funded projects to incorporate flood risk management standards that account for sea-level rise. By revoking this executive order, the Trump Administration adopts a new floodplain risk management strategy that restricts the definition of floodplain, thereby allowing more real estate development in flood-prone areas, rejects determinations of risk based on "a climate-informed science approach," and no longer requires federal agencies to incorporate climate science into the analysis. The decisions of the Trump Administration are not only inconsistent with past decisions of the Obama Administration on climate change adaptation but are at odds with prevailing science-based risk management measures advocated by scientists and policy-makers.

During the Obama Administration, the President's Climate Action Plan directed federal agencies to support climate-resilient investments. For example, the plan directed the Department of Housing and Urban Development (HUD) to require grant recipients funded with supplemental appropriations for Hurricane Sandy response to take sea-level rise into account in their projects and activities. Federal agencies have made other climate-resilient investments. HUD, for example, initiated the Rebuild by Design competition and provided $\$ 930$ million to fund projects that 
enhance disaster resilience in areas affected by Hurricane Sandy. One such project proposed building deployable walls attached to the underside of roads that could be used during flood events in Manhattan. In addition, several Federal Emergency Management Authority (FEMA) programs fund hazard mitigation measures to assist states and local governments in their efforts to enhance disaster resilience before disasters occur. Activities eligible for grants include property acquisition, elevation, and retrofitting. Programs such as the Hazard Mitigation Grant Program, Hazard Mitigation Assistance, Pre-disaster Mitigation Grant Program, Flood Mitigation Assistance, Repetitive Flood Claims, and Severe Repetitive Loss undertake these projects (Gotham 2012).

Several federal agencies and funding sources have played major roles in postKatrina and post-Sandy rebuilding efforts in New Orleans and New York. Following Hurricane Katrina, Congress authorized the US Army Corps of Engineers ("Corps") to design and construct the $\$ 14.6$ billion Hurricane and Storm Damage Risk Reduction System (HSDRRS) for southeast Louisiana. Over the past 10 years, the Corps has strengthened the levees, floodwalls, gated structures, and pump stations that form the 133-mile Greater New Orleans perimeter system in addition to improving approximately 70 miles of interior risk reduction structures (Gotham 2018). In Louisiana, state officials used $\$ 10.5$ billion in HUD funds from the Community Development Block Grant (CDBG) program to create the Road Home program, which provided homeowners with up to $\$ 150,000$ to repair or rebuild damaged homes. Other Road Home funds were used to elevate homes (for a critical overview, see Gotham 2014a). Like FEMA's Hazard Mitigation Grant program, policy-makers designed the Road Home as a resilience-enhancing program, though scholars have raised questions about the overall effectiveness of the Road Home program in achieving resilience goals and outcomes (Gotham 2014b).

Other federal funding sources including the Water Resources Development Act (WRDA) and the Coastal Wetlands Planning, Protection, and Restoration Act (CWPPRA) (authorized by Congress in 1990) have been instrumental in funding coastal restoration and protection efforts in southern Louisiana. Following Hurricanes Gustav and Ike in 2008, the federal government provided \$27.4 million to Louisiana for coastal protection and restoration projects that help communities recover from the storms and better withstand future hurricanes. The CDBG funds went to the Louisiana Office of Community Development's Disaster Recovery Unit, which has partnered with the Coastal Protection and Restoration Authority (CPRA) to identify potential flood protection projects such as levee construction or improvements, floodgate installation, critical infrastructure, and shoreline protection. Through Fiscal Year 2015, the CPRA built or improved approximately 250 miles of levees, moved over 150 projects into design and construction phases, approved constructed projects in 20 parishes, and approved construction of 45 miles of barrier islands and berms. These projects represent a total state government investment of nearly $\$ 477$ million in FY 2015 (CPRA 2017).

In New York, the US Army Corps of Engineers and the State of New York raised $\$ 450$ million to construct new armored levees and other infrastructure along Midland Beach and Staten Island's East Shore. Funds were also allocated to invest in coastal 
protection in the Rockaways and the communities surrounding the Jamaica Bay area. In addition, HUD allocated $\$ 4.21$ billion in disaster aid through the Community Development Block Grant-Disaster Recovery (CDBG-DR) to create to the Business PREP (Preparedness and Resiliency Program). This was a new program to help small businesses better prepare for emergencies and enhance the resiliency of their operations, assets, and physical space. The $\$ 4.21$ billion in disaster aid helped spur new investment in several urban neighborhoods including the Rockaways, Staten Island, Coney Island, and Hunts Point (New York City Mayor's Office 2014). In 2015, New York City announced that it was using funds from HUD's Rebuild by Design, referred to above, to begin preliminary design work on the Lower East Side to implement a $\$ 335$ million integrated, neighborhood-sensitive flood protection system to mitigate risk. This project is "intended to be just the first phase of a larger project that will ultimately provide coastal resiliency for all of Lower Manhattan," according to the New York City Mayor's Office (2015).

The generation and distribution of climate change adaptation resources are mediated by the decentralized, fragmented structure of American federalism. This decentralized and fragmented structure localizes the funding mechanisms to generate the monetary resources to support climate change adaptation measures. State governments and localities have historically remained responsible for generating funds for urban revitalization. Consequently, uneven metropolitan development has been a permanent feature throughout US history (Gotham 2014c; Gotham 2001). Moreover, for most people, climate change is distant and remote compared to the everyday concerns of urban health, crime and safety, education, and housing. Governments have typically not included adaptive measures in their planning because they tend to focus their attention and resources on competing, shorter-term priorities like sustaining government services and raising funds to deal with infrastructure upkeep, repair, and long-term challenges. Adaptation is a relatively low priority compared with more traditional and immediate concerns such as managing aging infrastructure systems, sustaining current levels of service, protecting public health and safety, and maintaining service affordability (GAO 2013). Short-term competing priorities make it difficult for decision-makers to address the impacts of climate change, especially since many state and local governments responsible for infrastructure investment face immediate funding and staffing challenges. Given these institutional challenges, the formulation of coherent climate change adaptation policy remains elusive and extraordinarily difficult.

\subsection{Contradictory Roles of the Federal Government}

Recent years have witnessed three ominous developments that threatened to obstruct progress on reducing climate change risks. First, in March 2017, President Donald Trump, as part of his Fiscal Year 2018 budget request, introduced plans to eliminate the National Oceanic and Atmospheric Administration's (NOAA) National Sea Grant College Program, a 50-year old program that funds scientific research focused 
on climate change adaptation initiatives that will prepare coastal communities for the predicted impacts of climate change. In prior years, the program received $\$ 73$ million per year. Under the Trump budget, the program would have received no funding at all. The Sea Grant program oversees a network that includes the National Sea Grant Office, 33 university-based state programs, the National Sea Grant Advisory Board, the National Sea Grant Law Center, the National Sea Grant Library, and hundreds of other participating institutions. Also in his budget, Trump announced major cuts to NOAA's Office of Oceanic and Atmospheric Research, where climate research programs are housed. The office would see a $\$ 150$ million, or 19 percent, budget cut. Other NOAA programs to be zeroed out as part of the administration's budget request included the National Estuarine Research Reserve System, Coastal Zone Management Program grants, and the Pacific Coastal Salmon Recovery Fund. Over the past year, Congress has followed President Trump's lead by pushing for major budget cuts to the Environmental Protection Agency (EPA), such as $\$ 513$ million in cuts that would effectively terminate climate change adaptation programs such as the Climate Resilience Fund as well as broader environmental programs and management (Meade 2018; Thwaites 2018). While the House ignored the President's budget request, rather increasing funding for Sea Grant and NOAA, the examples continue to be relevant because they reflect a lack of consensus between the legislative and executive branches on funding for climate change mitigation and adaptation.

Second, in President Trump's first budget proposal for Fiscal Year 2018, he proposed major cuts in federal funding for coastal restoration and protection efforts in Louisiana. The proposal upends the Gulf of Mexico Energy Security Act (GOMESA), which is a commitment from Congress to share offshore energy revenues with four of the Gulf states that are impacted by its production. GOMESA is projected to provide approximately $\$ 100$ million per year beginning in 2017 . Congress has dictated that GOMESA funds be used for projects and activities for the purposes of coastal protection, including conservation, coastal restoration, hurricane protection, and infrastructure directly affected by coastal wetland losses. President Trump's proposal follows Obama Administration 2016 and 2017 budgets for the Department of Interior that contained language to redirect GOMESA revenue to broader national programs. GOMESA is a revenue-sharing program that, while estimated to provide substantial long-term funding for climate change adaptation, is not guaranteed across a multi-decade time horizon. A major contradiction in relying on GOMESA to fund climate change adaptation efforts is that GOMESA revenues depend on the continued profitability of offshore oil and gas production, a major producer of GHGs that are the source of global warming and subsequent sea-level rise (Mogensen 2018; Reardon et al. 2017; Selby n.d.).

Third, closely related to recent executive branch efforts to erect roadblocks to climate change adaptation has been a strong political consensus among elected leaders to deny or dismiss the scientific consensus on the extent of climate driven sea-level rise, its significance, and its connection to coastal erosion. In Louisiana, many elected officials have been prominent climate change deniers, calling into question the science behind global warming and adamantly opposing legislation to 
reduce GHGs that contribute to rising sea levels. Over the years, Louisiana's congressional delegation has voted against legislation that would have factored global warming into federal project planning; voted in favor of barring the EPA from regulating GHGs; voted against enforcing limits on $\mathrm{CO} 2$ global warming pollution; voted against tax credits for renewable electricity; voted for tax incentives for fossil fuel energy production; voted against tax incentives for renewable energy; voted against removing oil and gas exploration subsidies and against keeping a moratorium on drilling for oil offshore (outside of Louisiana); voted for authorizing construction of new oil refineries; voted for barring GHGs from Clean Air Act rules; voted for letting the wind energy production tax credit expire; voted against reducing oil usage by 40 percent by 2025 (instead of 5 percent); voted against factoring global warming into federal project planning; voted against implementation of the Kyoto Protocol; voted against including oil and gas smokestacks in mercury regulations (September 2005); and voted to appoint Scott Pruitt—a climate change denier who has sued the EPA over emission regulations - to head that agency (Marshall 2017).

In 2011, US House of Representative member Steve Scalise helped pass an amendment to the Agriculture Appropriations Bill prohibiting funds from being used to implement a new US Department of Agriculture (USDA) regulation requiring agencies to spend taxpayer dollars to study and implement climate change policies and initiatives. The amendment passed by a vote of 238 to 179. Senator Scalise signed the No Climate Tax Pledge and voted for amending the Clean Air Act to prohibit the EPA from promulgating any regulation on the emission of a greenhouse gas to address climate change. He also voted against proposed legislation to require utilities to supply an increasing percentage of their demand from a combination of energy efficiency savings and renewable energy. In 2009, he signed HR 391 to amend the Clean Air Act to declare that nothing in the Act shall be treated as authorizing or requiring the regulation of climate change or global warming. As one journalist put it:

\footnotetext{
No landscape in the nation is more threatened by global warming, yet our delegation has consistently voted against carbon legislation at the urging of industry and have voted for bills that would prohibit federal agencies from even studying global warming. Naturally, that has congress people in other states asking the question: Why should we pour billions into rebuilding Louisiana's coast, if their own delegation isn't going to address one of the main causes of its loss? (Marshall 2012)
}

Climate change denial expresses the mounting political and economic stakes of dealing with the risks of anthropogenic climate change. Conservative think tanks, conservative media, corporations, and industry associations (especially for the fossil fuels industry) — domains dominated by conservative white males-have spearheaded the attacks on climate science and policy from the late 1980s to the present (Dunlap and McCright 2011; Freudenburg and Muselli 2010; Lahsen 2008; McCright and Dunlap 2003, 2010, 2011a, b; Oreskes and Conway 2010). Organized climate change denial has an elective affinity with established conservative think tanks that promote free-market conservatism and front groups promoting industry interests. Sustained climate change denial, promoted largely by the American 
conservative movement (Dunlap and McCright 2011; McCright and Dunlap 2003, 2010), contributes to political polarization on climate change beliefs (McCright and Dunlap 2011b). This organized "climate change denial movement" has mobilized to undercut public belief in climate science and discourage political support for climate change risk reduction measures and adaptation measures (Dunlap and McCright 2011; Oreskes and Conway 2010; McCright and Dunlap 2010; Powell 2011). The political effect of climate change denial is to off-load the cost of paying for climate change risk reduction to other more vulnerable groups while simultaneously protecting the profiteering interests of the GHG production economy.

\subsection{Conclusions}

Since the establishment of the Intergovernmental Panel on Climate Change in 1988, the potential impacts of global climate change have captured the attention of the natural and physical scientists, the international research community, and the policymakers around the world. As the human causes and consequences of climate change have become increasingly apparent, scholars and government leaders have called on social scientists to contribute to the scientific understanding of the role of humans in global climate change (for overviews, see Dunlap and Brulle 2015; Nagel et al. 2010). Social scientists debate the short-term and long-term climate impacts on cities and communities around the world. Different nations will have to balance a variety of value-laden considerations related to the impacts of climate change itself, potential costs of mitigation and adaptation, and collective struggles over the appropriate societal response. The difficulty of these tasks is compounded by the need to develop a consensus on fundamental issues such as the level of risk that societies are willing to accept and impose on others, strategies for sharing costs, and planning for unforeseen consequences. These tasks and issues are intertwined with relations of domination and subordination. Different actors and organized interests have varied political-economic prerogatives, and the political system offers differential and unequal access to decision-making power. Thus, any examination of the global social problem of climate change must address the question of adaptation "for whom" and "for what purpose."

In spite of the federal disaster resources directed to New York and New Orleans, the federal government has an inherently limited role in the project-level planning processes central to adapting infrastructure to climate change because these are typically the responsibility of state and local governments. That is, state and local authorities are primarily responsible for prioritizing and supervising the implementation of climate change adaptation measures and projects. Therefore, for the foreseeable future, both New York and New Orleans as well as US cities in general face a constrained situation of poor funding and limited options for raising money. On the one hand, different communities can use a variety of sources to fund capital projects, pay for operations and maintenance costs, and sustain programs. These funding sources can include (1) taxes such as property, sales, and income 
levies; (2) fees such as charges for inspections and permits; (3) state and federal grants such as those that support improvements to drinking water, wastewater, and storm water systems; (4) bonds which enable communities to borrow money to pay for projects; (5) loans to pay for projects and programs; and (6) public-private partnerships that entail contractual agreements between a public agency and a private sector entity allowing for cooperation and collaboration in the financing, planning, design, construction, and maintenance of water infrastructure.

On the other hand, the particular mix of funding sources and the amount they are capable of generating varies across communities depend on the level of wealth of the tax base, environmental circumstances, and specific community needs. In the United States, the formulation and implementation of climate change adaptation measures work through a complex system of multilevel governance that involves a plethora of statutes, laws, financing mechanisms, administrative capacities, and multiple overlapping and interconnected horizontal and vertical lines of authority. According to a 2010 National Research Council study, no one-size-fits-all adaptation option exists for a particular climate impact because climate change vulnerabilities can vary significantly by infrastructure category, region, community, or institution. Thus, the scale of the urban is of central importance in understanding similarities and differences in the process and patterns of climate change policymaking as well as the outcomes of climate adaptation measures (Bulkeley and Betsill 2013). That is, cities are not only the targets of climate change policy-making but are the locus of political conflicts over the nature and character of climate change adaptation. Cities are creatures of state governments, and state governments are, in turn, constituted by the laws and statutes of the US federal government. Conflicts and struggles over climate change policy and action do not take place in discrete local, national, and international arenas. Rather, climate change politics and policy outcomes express changing cross-scale interactions and complex vertical linkages between local actions, state government institutions, and the higher levels of the US federal government.

Today, many cities in the United States face a situation of chronic fiscal retrenchment, declining federal resources to fund climate change adaptation efforts, and broad hostility to the science of climate change. What the cases of New York and New Orleans show us is that taking steps to implement climate change adaptation measures is difficult for several reasons. Adaptation efforts tend to be expensive and require long-term, concerted planning and consensus building. More important, political and economic elites and elected officials typically oppose adaptation investments until faced with response and recovery expenditures once a disaster has occurred. Additionally, of critical importance is the fact that within the US federal system, the adoption and implementation of many adaptation activities fall within the purview of local governments, and those governmental units are typically influenced by powerful and organized economic development interests that are most likely to oppose adaptation. Moreover, it has only been in the last decade or so that federal funds for adaptation became available to communities, but the future of those funds is uncertain. Consequently, the current US climate change adaptation landscape is a patchwork of differing approaches in which some communities and 
regions are afforded some protection from some climate risks (but not others), while others remain highly vulnerable to the negative impacts of global climate change.

We conclude with several policy recommendations to facilitate and enable more informed decisions about adaptation. Current efforts include raising public awareness of the adverse impacts of climate change, improving infrastructure decision-makers' access to and use of available climate-related information, providing increased access to local assistance, and considering climate change in existing planning processes (for overviews, see GAO 2013; Dunlap and Brulle 2015). These are important, but we think policy recommendations should embrace an equity-oriented and social justice-based focus. That is, the goal of climate change adaptation cannot lie just in consciousness raising through public awareness campaigns or in the implementation of conventional systems of financing (bond programs, tax incentives, etc.). Rather, climate change adaptation requires an effort to integrate and coordinate housing, infrastructure, and economic development programs with comprehensive, publically financed, and democratically run programs with clear accountability systems. Cross-scale, collaborative governance could enhance the flexibility and spatial targeting of incentives to reduce vulnerability and also provide an institutional foundation for direct participation of community residents in program design, implementation, and oversight responsibilities. The creation of jobs that pay a living wage, adequate benefits for those who cannot work, access to affordable health care, and increased supply of affordable housing might also improve the effectiveness of climate change adaptation programs, especially for low-income and moderate-income communities that face the highest levels of vulnerability to climate change impacts. Developing public and private sector funding criteria to match communities' evolving vulnerability pressures, combined with public works programs, could enhance prospects for achieving equitable climate change adaptation for communities.

\section{References}

Blum, M. D., \& Roberts, H. H. (2009). Drowning of the Mississippi Delta due to insufficient sediment supply and global sea-level rise. Nature Geoscience, 2, 488-491.

Bulkeley, H., \& Betsill, M. M. (2013). Revisiting the urban politics of climate change. Environmental Politics, 22(1), 136-154.

Bulkeley, H., \& Castán Broto, V. (2013). Government by experiment? Global cities and the governing of climate change. Transactions of the Institute of British Geographers, 38(3), 361-375.

Burch, S., Shaw, A., Dale, A., \& Robinson, J. (2014). Triggering transformative change: A development path approach to climate change response in communities. Climate Policy, 14(4), 467-487.

Campanella, R. (2017). Delta urbanism: New Orleans. New York, NY: Routledge.

Campbell, J. L., \& Lindberg, L. N. (1990). Property righs and the organization of economic activity by the state. American Sociological Review, 55, 634-647.

Campbell, J. L., \& Pedersen, O. K. (2014). The national origins of policy ideas: Knowledge regimes in the United States, France, Germany, and Denmark. Princeton, NJ: Princeton University Press. 
Coastal Protection and Restoration Authority of Louisiana (CPRA). (2017). Louisiana's comprehensive master plan for a sustainable coast. Baton Rouge, LA: OTS-State Printing.

Couvillion, B. (2017). USGS: Louisiana's rate of coastal wetland loss continues to slow. Washington, DC: U.S. Department of Interior, United States Geological Survey. https://www. usgs.gov/news/usgs-louisiana-s-rate-coastal-wetland-loss-continues-slow

Dale, A., Burch, S., Robinson, J., \& Strashok, C. (2018). Multilevel governance of sustainability transitions in Canada: Policy alignment, innovation, and evaluation. In S. Hughes, E. Chu, \& S. Mason (Eds.), Climate change in cities (pp. 343-358). Cham, Switzerland: Springer.

Dunlap, R. E., \& Brulle, R. J. (2015). Climate change and society: Sociological perspectives. New York: Oxford University Press.

Dunlap, R. E., \& McCright, A. M. (2011). Organized climate change denial. In J. S. Dryzek, R. B. Norgaard, \& D. Schlosberg (Eds.), The Oxford handbook of climate change (pp. 144-160). London, UK: Oxford.

Eakin, H. C., Lemos, M. C., \& Nelson, D. R. (2014). Differentiating capacities as a means to sustainable climate change adaptation. Global Environmental Change, 27, 1-8.

Eisenack, K., Moser, S. C., Hoffmann, E., Klein, R. J., Oberlack, C., Pechan, A., et al. (2014). Explaining and overcoming barriers to climate change adaptation. Nature Climate Change, 4(10), 867-872.

Exec. Order No. 13653 (2013), 78 C.F.R. 66819.

Exec. Order No. 13690 (2015), 80 C.F.R. 6425.

Feagin, J. R., \& Parker, R. (2002). Building American cities: The urban real estate game. New York: Beard Books.

Fischbach, J. R., Johnson, D. R., Ortiz, D. S., Bryant, B. P., Hoover, M., \& Ostwald, J. (2012). Coastal Louisiana risk assessment model. Santa Monica, CA: Rand Corporation.

Freudenburg, W. R., \& Muselli, V. (2010). Global warming estimates, media expectations, and the asymmetry of scientific challenge. Global Environmental Change, 20, 483-491.

González, J. L., \& Törnqvist, T. E. (2006). Coastal Louisiana in crisis: Subsidence or sea-level rise? Eos, 87, 493-498.

González, J. L., \& Törnqvist, T. E. (2009). A new Late Holocene sea-level record from the Mississippi Delta: Evidence for a climate/sea-level connection? Quaternary Science Reviews, 28, 1737-1749.

Gotham, K. F. (Ed.). (2001). Critical perspectives on urban redevelopment: Research in urban sociology (Vol. 6). New York, NY: Emerald Press.

Gotham, K. F. (2006). The secondary circuit of capital reconsidered: Globalization and the US real estate sector. American Journal of Sociology, 112(1), 231-275.

Gotham, K. F. (2009). Creating liquidity out of spatial fixity: The secondary circuit of capital and the subprime mortgage crisis. International Journal of Urban and Regional Research, 33(2), 355-371.

Gotham, K. F. (2012). Disaster, Inc.: Privatization and post-Katrina rebuilding in New Orleans. Perspectives on Politics, 10, 633-646.

Gotham, K. F. (2014a). Racialization and rescaling: Post-Katrina rebuilding and the Louisiana Road Home Program. International Journal of Urban and Regional Research, 38(3), 773-790.

Gotham, K. F. (2014b). Reinforcing inequalities: The impact of the CDBG program on postKatrina rebuilding. Housing Policy Debate, 24(1), 192-212.

Gotham, K. F. (2014c). Race, real estate, and uneven development: The Kansas City experience, 1900-2010. Albany, NY: State University of New York Press.

Gotham, K. F. (2016a). Antinomies of risk reduction: Climate change and the contradictions of coastal restoration. Environmental Sociology, 2(2), 208-219.

Gotham, K. F. (2016b). Coastal restoration as contested terrain: Climate change and the political economy of risk reduction in Louisiana. Sociological Forum, 31(S1), 787-806.

Gotham, K. F. (2018). Katrina is coming to your city: Storm and flood defense infrastructures in risk society. Forthcoming in C. Ermus (Ed.), Environmental disaster in the gulf south: Two centuries of catastrophe, risk, and resilience (pp. 161-83). Baton Rouge: Louisiana State University Press. 
Gotham, K. F., \& Campanella, R. (2010). Toward a research agenda on transformative resilience: Challenges and opportunities for post-trauma urban ecosystems. Critical Planning, 17(Summer), 9-23.

Gotham, K. F., \& Campanella, R. (2011). Coupled vulnerability and resilience: The dynamics of cross-scale interactions in post-Katrina New Orleans. Ecology and Society, 16(3), 12.

Gotham, K. F., \& Cannon, C. (2018). Circulating risks: Coastal cities and the specter of climate change risk. In A. Jonas (Ed.), Routledge handbook on spaces of urban politics (pp. 383-403). New York, NY: Routledge.

Gotham, K. F., \& Cheek, W. (2017). Post-disaster recovery and rebuilding. Forthcoming in S. Hall \& R. Burdett (Eds.), The Sage handbook of the 21st century city (pp. 279-297). Thousand Oaks, CA: Sage Publications.

Gotham, K. F., \& Greenberg, M. (2014). Crisis cities: Disaster and redevelopment in New York and New Orleans. New York, NY: Oxford University Press.

Gotham, K. F., \& Powers, B. (2017). Constructing and contesting resilience in post-disaster urban communities. In J. Hannigan \& G. Richards (Eds.), Sage handbook of new urban studies (pp. 139-154). Thousand Oaks, CA: Sage Publications.

Gotham, K. F., \& Wright, J. D. (2009). Housing policy. In J. Midgley, M. Livermore, \& M. B. Tracy (Eds.), Handbook of social policy (2nd ed., pp. 237-255). Thousand Oaks, CA: Sage Publications.

Gotham, K. F., Campanella, R., Lewis, J., Gafford, F., Nance, E., \& Avula, M. R. (2011). Reconsidering the new normal: Vulnerability and resilience in post-Katrina New Orleans. Global Horizons: The Journal of Global Policy and Resilience, 4, 2.

Government Accountability Office (GAO). (2009). Climate change adaptation: Strategic federal planning could help government officials make more informed decisions (GAO-10113). Washington, DC: Govenrment Accountability Office. https://www.gao.gov/assets/300/ 296526.pdf

Government Accountability Office (GAO). (2013). High-risk series: An update (GAO-13-283). Washington, DC: Government Accountability Office. https://www.gao.gov/products/ GAO-13-283

Government Accountability Office (GAO). (2016). Climate change: Selected governments have approached adaptation through laws and long-term plans (GAO-16-454). Washington, DC: Government Accountability Office. https://www.gao.gov/assets/680/677075.pdf

Grinsted, A., Moore, J. C., \& Jevrejeva, S. (2013). Projected Atlantic hurricane surge threat from rising temperatures. Proceedings of the National Academy of Sciences, 110(14), 5369-5373.

Hallegatte, S., Green, C., Nicholls, R. J., \& Corfee-Morlot, J. (2013). Future flood losses in major coastal cities. Nature Climate Change, 3(9), 802-806.

Hogan, J., \& Howlett, M. (Eds.). (2015). Policy paradigms in theory and practice: Discourses, ideas and anomalies in public policy dynamics. New York, NY: Springer.

Holland, G. J. (2012). Hurricanes and rising global temperatures. Proceedings of the National Academy of Sciences, 109(48), 19513-19514.

Horton, R., Little, C., Gornitz, V., Bader, D., \& Oppenheimer, M. (2015). New York City panel on climate change 2015 report: Sea-level rise and coastal storms. Annals of the New York Academy of Sciences, 1336(1), 36-44.

Intergovernmental Panel on Climate Change (IPCC). (2007). Climate change 2007: Synthesis report, summary for policymaker. Washington, DC: Intergovernmental Panel on Climate Change.

Intergovernmental Panel on Climate Change (IPCC). (2013). Climate Change 2013: The Physical Science Basis. Contribution of Working Group I to the Fifth Assessment Report of the Intergovernmental Panel on Climate Change. New York, NY: Cambridge University Press.

Intergovernmental Panel on Climate Change (IPCC). (2014). Climate change 2014 - Impacts, adaptation and vulnerability: Regional aspects. New York, NY: Cambridge University Press.

Intergovernmental Panel on Climate Change Adaptation Task Force. (2011). National action plan: Priorities for managing freshwater resources in a changing climate. Washington, DC: Intergovernmental Panel on Climate Change. 
Karl, T. R., Melillo, J. M., \& Peterson, T. C. (Eds.). (2009). Global climate change impacts in the United States. New York, NY: Cambridge University Press.

Kent, J. D. (2012). Assessing the long-term impact of subsidence and global climate change on emergency evacuation routes in coastal Louisiana: A report of findings. Gulf Coast Center for Evacuation and Transportation Resiliency. Principal Investigator: Joshua D. Kent, Ph.D. Baton Rouge, LA: Center for GeoInformatics, Louisiana State University. http://www.evaccenter.lsu. edu/pub/11-09.pdf

Kolb, C. R., \& Saucier, R. T. (1982). Engineering geology of New Orleans. In Geological Society of America. Reviews in Engineering Geology, 5, 75-94. https://doi.org/10.1130/REG5-p75.

Lahsen, M. (2008). Experiences of modernity in the greenhouse. Global Environmental Change, 18, 204-219.

Marshall, B. (2012, May 29). Approval of 2012 master plan for the Coast is worth celebrating. The Times-Picayune. http://www.nola.com/outdoors/index.ssf/2012/05/approval_of_2012_master_plan_f.html

Marshall, B. (2017, May 15). Louisiana keeps voting to drown: Opinion. The Times-Picayune. http://www.nola.com/opinions/index.ssf/2017/05/louisiana_eroding_coast.html

McCann, E. (2017). Mobilities, politics, and the future: Critical geographies of green urbanism. Environment and Planning, 49(8), 1816-1823.

McCright, A. M., \& Dunlap, R. E. (2003). Defeating Kyoto: The conservative movement's impact on U.S. climate change policy. Social Problems, 50, 348-373.

McCright, A. M., \& Dunlap, R. E. (2010). Anti-reflexivity: The American conservative movement's success in undermining climate science and policy. Theory, Culture, and Society, 27(23), 100-133.

McCright, A. M., \& Dunlap, R. E. (2011a). The politicization of climate change and polarization in the American public's views of global warming, 2001-2010. The Sociological Quarterly, 52(2), 155-194.

McCright, A. M., \& Dunlap, R. E. (2011b). Cool dudes: The denial of climate change among conservative white males. Global Environmental Change, 21, 1163-1172.

Meade, N. (2018, July 7). Trump's cuts in climate-change research spark a global scramble for funds. New Yorker. https://www.newyorker.com/news/news-desk/ trumps-cuts-in-climate-change-research-spark-a-global-scramble-for-funds

Mogensen, J. L. (2018, September 10). New documents show the Trump Administration cut climate change impacts from its energy plan. Huffington Post. https://www.huffingtonpost.com/ entry/new-documents-show-the-trump-administration-cut-climate-change-impacts-from-itsenergy-planus5b9686fee4b0cf7b004222cb

Morrison, T. H., Adger, W. N., Brown, K., Lemos, M. C., Huitema, D., \& Hughes, T. P. (2017). Mitigation and adaptation in polycentric systems: Sources of power in the pursuit of collective goals. Wiley Interdisciplinary Reviews: Climate Change, 8, 5, e479.

Nagel, J., Dietz, T., \& Broadbent, J. (2010). Workshop on sociological perspectives on global climate change, May 30-31, 2008. Sociology Program, Directorate for Social, Behavioral and Economic Sciences, National Science Foundation (MSF). Washington, DC: American Sociological Association. http://www.asanet.org/sites/default/files/savvy/research/ NSFClimateChangeWorkshop_120109.pdf

National Research Council. (2010). Informing an effective response to climate change. Washington, DC: The National Academies Press. https://doi.org/10.17226/12784.

National Research Council. (2012a). Climate change: Evidence, impacts, and choices. Answers to common questions about the science of climate change. Washington, DC: The National Academies Press.

National Research Council. (2012b). Disaster resilience: A national imperative. Washington, DC: The National Academies Press. https://doi.org/10.17226/13457.

New York City Mayor's Office. (2014). Mayor de Blasio announces key resiliency investments to support small businesses and jobs, including new business resiliency program and major upgrades across Sandy-impacted neighborhoods. Official Website of the City of New York. http://www1.nyc.gov/office-of-the-mayor/news/568-14/mayorde-blasio-key-resiliency-investments-support-small-businesses-jobs 
New York City Mayor's Office. (2015). Mayor de Blasio releases NPCC 2015 report, providing climate projections through 2100 for the first time. Official Website of the City of New York. http://www1.nyc.gov/office-of-the-mayor/news/122-15/mayor-de-blasioreleases-npcc-2015-report-providing-climate-projections-2100-the-first

Oreskes, N., \& Conway, E. M. (2010). Merchants of doubt: How a handful of scientists obscured the truth on issues from tobacco smoke to global warming. New York, NY: Bloomsbury Press.

Pelling, M., O’Brien, K., \& Matyas, D. (2015). Adaptation and transformation. Climatic Change, 133(1), 113-127.

Peyronnin, N., Green, M., Richards, C. P., Owens, A., Reed, D., Chamberlain, J., et al. (2013). Louisiana's 2012 coastal master plan: Overview of a science-based and publicly informed decision-making process. Journal of Coastal Research, 67(1), 1-15. https://doi.org/10.2112/ si_67_1.1.

Powell, J. L. (2011). The inquisition of climate science. New York, NY: Columbia University Press.

Reardon, S., Tollefson, J., Witze, A., \& Ross, E. (2017). US science agencies face deep cuts in trump budget. Nature News, 543(7646), 471.

Reed, A. J., Mann, M. E., Emanuel, K. A., Lin, N., Horton, B. P., Kemp, A. C., et al. (2015). Increased threat of tropical cyclones and coastal flooding to New York City during the anthropogenic era. Proceedings of the National Academy of Sciences, 112(41), 12610-12615.

Selby, J. (n.d.). The Trump presidency, climate change, and the prospect of a disorderly energy transition. Review of International Studies, 1-20. https://doi.org/10.1017/S0260210518000165.

Thwaites, J. (2018). US 2018 budget and climate finance: It's bad, but not as bad as you might think. (Blog). World Resources Institute. 23 March. https://www.wri.org/blog/2018/03/ us-2018-budget-and-climate-finance-its-bad-not-bad-you-might-think

Tierney, K. (2014). The social roots of risk: Producing disasters, promoting resilience. Palo Alto, CA: Stanford University Press.

Tilly, C. (1984). Big structures, large processes, huge comparisons. New York: Russell Sage Foundation.

U.S. Army Corps of Engineers (USACE). (2018). Project planning: National nonstructural committee (NIC). U.S. Army Corps of Engineers. https://www.usace.army.mil/Missions/CivilWorks/Project-Planning/nfpc/.vlCo

United States Global Change Research Program (USGCRP). (2011). America's climate choices. Washington, DC: U.S. Global Change Research Program. http://www.globalchange.gov/ what-we-do/assessment.

Wang, F., Xu, Y. J., \& Dean, T. J. (2011). Projecting climate change effects on forest net primary productivity in subtropical Louisiana, USA. Ambio, 405, 506-520.

Wise, R. M., Fazey, I., Smith, M. S., Park, S. E., Eakin, H. C., Van Garderen, E. A., et al. (2014). Reconceptualising adaptation to climate change as part of pathways of change and response. Global Environmental Change, 28, 325-336.

Open Access This chapter is licensed under the terms of the Creative Commons Attribution 4.0 International License (http://creativecommons.org/licenses/by/4.0/), which permits use, sharing, adaptation, distribution and reproduction in any medium or format, as long as you give appropriate credit to the original author(s) and the source, provide a link to the Creative Commons license and indicate if changes were made.

The images or other third party material in this chapter are included in the chapter's Creative Commons license, unless indicated otherwise in a credit line to the material. If material is not included in the chapter's Creative Commons license and your intended use is not permitted by statutory regulation or exceeds the permitted use, you will need to obtain permission directly from the copyright holder.

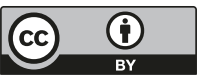

